\title{
Hemşirelerin Öz Yeterlilik İnanç Düzeylerinin Performansları Üzerindeki Etkisi: Elazığ İli Örneği
}

\author{
Eray Ekin SEZGINN ${ }^{1}$ ve Muhammet DÜȘÜKCAN ${ }^{2}$
}

\section{Öz}

Bu çalışma ile Elazığ il merkezindeki hastanelerde görev yapan hemşirelerin öz yeterlilik inanç düzeylerinin ne seviyede olduğunu ve bu inançlarının performanslarına ne şekilde etki ettiğinin ortaya konulması amaçlanmıştır. Elazığ il merkezinde faaliyet gösteren hastanelerin hemşireleri, araştırmanın evrenini oluşturmaktadır. Elazı̆̆ il merkezinde 4'ü kamuya ve 4'ü özel sektöre ait olmak üzere toplam 8 hastane yer almaktadır. Bu hastanelerde toplam 1535 hemşire istihdam edilmektedir. Araştırmanın örneklemini evreni temsilen tesadüfi seçilen 309 hemşire oluşturmuştur. Çalışmada nicel araştırma yöntemi kullanılmış ve veriler yüz yüze anket tekniği ile elde edilmiştir. Çalışmada kullanılan başlıca analizler; betimleyici istatistikler, güvenilirlik analizleri ve regresyon analizleri şeklindedir. Araştırma sonucunda hemşirelerin öz yeterlilik inanç düzeylerinin $(\bar{X}=4,27$; ss $=0,52)$ ve performanslarının $(\bar{X}=4,11$; ss $=0,64)$ yüksek olduğu ortaya çıkmıştır. Öz yeterlilik inanç düzeylerinin çalışan performansı üzerindeki etkisinin pozitif yönde ve düşük olduğu saptanmıştır. Öz yeterlilik çalışan performansı üzerinde \% 6 oranında etkili olabilmektedir $(\mathrm{r}=0,253 ; \mathrm{r} 2=0,064 ; \mathrm{p}<0,001)$.

Anabtar Kelimeler: Sağlık işletmeleri, Öz yeterlilik, Çalışan performansı, Hemşireler

The Effect of the Level of Self-Efficacy Confidence of the Nurses on Their Performance: Example of Elazig Province

\begin{abstract}
With this study, it was aimed to determine the level of self-efficacy beliefs and how these beliefs affect their performance of nurses working in hospitals in the city of Elazig. Nurses of hospitals operating in the city of Elazig constitute the universe of research. There are a total of 8 hospitals including 4 public and 4 private in Elazig. A total of 1,535 nurses are employed in these hospitals. The sample consists of 309 randomly selected nurses representing the universe. In this study, the quantitative research method has been used and data obtained through the face-toface survey technique. In this study, the main statistical analyses used are descriptive statistics, reliability analysis and regression. The study findings showed that the nurses' self-efficacy belief levels $(\bar{X}=4.27 ; \mathrm{sd}=0.52)$ and performances $(\bar{X}=4.11 ; \mathrm{sd}=0.64)$ was high. Self-efficacy belief levels was found to have a positive low effect on employee performance. Self-efficacy may be effective at a rate of $6 \%$ on employee performance $(r=0.253 ; r 2=0.064 ; p<0.001)$.
\end{abstract}

Key Words: Healthcare businesses, Self-efficacy, Employee performance, Nurses

\section{Atıf İçin / Please Cite As:}

Sezgin, E. E. ve Düşükcan, M. (2020). Hemşirelerin öz yeterlilik inanç düzeylerinin performansları üzerindeki etkisi: Elazığ ili örneği. Manas Sosyal Araștırmalar Dergisi, 9(3), 1689-1702.

Geliş Tarihi / Received Date: 06.03.2019

Kabul Tarihi / Accepted Date: 12.05.2020

\footnotetext{
1 Dr. Öğr. Üyesi - Munzur Üniversitesi, İ̈BF, eraysezgin@munzur.edu.tr - ORCID: 0000-0002-8565-0269

2 Doç. Dr. - Firat Üniversitesi, İiBF, mdusukcan@firat.edu.tr - ORCID: 0000-0001-5742-1787
} 


\section{Giriş}

Günümüzde hastaneler rekabet üstünlüğü elde etmek ve elde ettikleri bu rekabet üstünlügünü sürdürebilmek için insan kaynağını en etkin ve verimli şekilde kullanmalıdır. Küreselleşmenin de etkileri ile her türlü kaynağa daha kolay ulaşma firsatı olan sağlık işletmelerinin, rekabette farklılık yaratmak için en önemli kaynağı şüphesiz ki insan kaynağıdır. İşletmeler ancak insan kaynağını en etkin ve verimli şekilde kullanarak farklılık yaratabilirler. Bu bağlamda, kişilerin belli bir hedef veya görevi gerçekleştirebilme kapasitelerine ilişkin bireysel alg1, değerlendirme veya inançları olarak ifade edilen ve özellikle Türkiye bağlamında incelenmesine ihtiyaç olduğu değerlendirilen öz yeterlilik inancı kavramı da bu çerçevede çalısmaya temel olmuş, çalışanların performansı üzerinde etkili bir unsur olarak ele alınmış ve incelenmiştir.

Albert Bandura, öz-yeterlilik inancı kavramını "kişinin, bir işi yapmak için ihtiyaç duyduğu yetenek ve kabiliyete sahip olduğuna dair inancı" olarak tanımlamıştır (Heslin ve Khele, 2006, s. 705). Bandura’nın öz yeterlilik ile ilgili diğer bir tanımı da, "çeşitli durumlarla başa çıkabilmek için gereken davranışların ne kadar iyi ortaya konulabileceği ile ilgili kişisel yargilar"dır (Bandura, 1994). Bu çerçevede öz-yeterlilik inancı en basit haliyle, kişilerin kendi yetkinliklerine ilişkin bireysel değerlendirmeleri veya inançları olarak da ifade edilebilir.

Bandura'ya göre kişinin etkili bir şekilde sonuca ya da yüksek performansa ulaşabilmesi için gerekli beceri ve yeteneklere sahip olması en önemli etkendir (Spector, 2008, s. 208). Ayrıca Bandura'ya göre kişilerin sahip oldukları öz yeterlilik inançlarının yüksek olması bireysel çabaları ve iş devamlılıkları üzerinde de olumlu etkilere sahiptir. Bu olumlu etkiler çalışanların performanslarını ve çalısma sonuçlarını da olumlu yönde etkileyecektir (Heslin ve Khele, 2006, s. 705). Kişilerin uzman oldukları konuda daha fazla gelişmeleri, zor hedef ve görevler belirleyerek bu hedef ve görevlere sıkı sıkıya bağlanmaları öz yeterlilik hakkında olumlu bir inanç ile mümkün olacaktır. Yani bir kişinin öz yeterlilik inancının olumlu olması, zor hedef ve görevlerde veya olumsuz bir durum karşısında yılmalarına engel olur hatta çabalarını arttırarak bu olumsuzluğun üstüne gitmeleri konusunda kişiyi teşvik eder (Bandura, 1994).

Örgüt çalışanlarının performanslarının artması kendilerinin öz yeterlilik inanç düzeylerinin yükselmesi ile ilişskilidir ve bu nedenle öz yeterlilik çalışanların performanslarını doğrudan etkilemektedir (Bandura, 1994). Lee ve Ko (2010) hemşirelerin öz yeterliliklerinin kendi performansları üzerindeki etkisini belirlemeye yönelik yaptıkları çalışmada, iki kavram arasında pozitif yönlü anlamlı bir ilişskinin olduğunu saptamışlardır. Yani hemşirelerin öz yeterlilik inançlarının yükselmesinin kendi performanslarına da doğrudan yansıdığ görülmüştür.

Hastanelerin rekabet edebilmesi ve rekabet avantajını sürdürebilmesi için insan kaynağını etkin ve verimli şekilde yönetmesi gerekmektedir. Hastaneler, tüm kaynaklara daha kolay ulaşabildikleri küresel dünyada, fark yaratmak için ellerindeki insan kaynağını en etkin ve verimli şekilde kullanmalıdır. Çalışan performansını kişisel, kültürel, sosyal ve örgütsel birçok değişken veya faktör kümesi etkilemektedir. Top, Gider ve Ünalan (2010) yaptıkları çalışmada, hastanelerde görev yapan hemşirelerin iş performanslarını etkileyen birtakım faktörler olduğunu dile getirmişlerdir. Bu faktörlerden bazılarının; klinik ve mesleki otonomi, hizmet içi eğitim, fiziksel iş koşulları, liderlik sitili, rol açıklığı, cinsel taciz, sosyal entegrasyon, vardiya uygulaması, stres, iş yükü vs. gibi değişkenler olduğunu ifade etmişlerdir (Top, Gider ve Ünalan, 2010). Bu örgütsel değişkenlere ilave olarak, hastanelerin verimli olması, çalışanların performanslarının üst düzeyde gerçekleşmesini etkileyen bir diğer faktör ise çalş̧anların sahip oldukları öz yeterlilik inançlarıdır. Hemşirelerin öz yeterlilik inanç düzeylerinin kendi performansları üzerinde önemli bir etkisi bulunduğu söylenebilir.

Bu çalışmanın temel amacı öz yeterlilik inancının performansa etkisini araştırmaktır. Bu doğrultuda, öncelikle öz yeterlilik ve performans kavramı ve aralarındaki ilişki incelenerek kavramsal çerçeve oluşturulmaya çalışılmışır. Daha sonra araştırmanın teorik çerçevesi ve temel hipotezi oluşturulmuştur. Çalışmanın araşıırma kısmında ise; Elazı̆̆ il merkezinde bulunan kamu ve özel hastanelerde görev yapan hemşirelerden toplanan veriler, istatistiki analize tabi tutulmuştur. Son olarak, analiz sonuçları değerlendirilmiş ve tartışılarak önerilerde bulunulmuştur. 


\section{Kuramsal Çerçeve}

\section{Öz Yeterlilik}

Bandura (1977)'nın sosyal öğrenme teorisinde kilit bir kavram olarak ifade edilen öz yeterlilik, bireyin hedeflerine ulaşma ve zorlukların üstesinden gelme yetenekleriyle ilgili inançları olarak tanımlanır (McCauley, Weymouth, Feinberg ve Fosco, 2019, s. 29). Özyeterlilik, bireyin kendisine verilen bir görevi yerine getirme yeteneğine olan inancı olarak da ifade edilmektedir (Muslichah, 2018, s. 23). Spesifik olarak, Bandura (1997), öz yeterliliklerin göreve ve içeriğe özgü olduğunu vurgulamıştır (Cattelino, Morelli, Baiocco ve Chirumbolo, 2019, s. 128).

Öz yeterlilik, insan faaliyetlerinin yol gösterici faktörlerinden biridir. Öz yeterlilik, insan davranışını doğrudan, bireyin motivasyon, düşence kalıpları gibi izlenimlerini ise dolaylı olarak etkiler (Latikka, Turja ve Oksanen, 2019, s. 158). Öz yeterlilik bir bireyin belirli bir durumu veya görevi başarmak için ne kadar ve ne süreyle çaba sarf ettiği ile ilgilidir.

Öz yeterlik inançları, insanların hangi faaliyetlere katılmak istedikleri, ne kadar çaba sarf etmeleri gerektiği ve faaliyetler zorlaşırsa, devam etmek isteyip istemedikleri konusunda karar vermelerine yardımc1 olur (Goodwin, 2016, s. 6). Locke vd. (1986) bireylerin yaşadıkları zorluklara rağmen çaba sarf etmelerinin ve hayatlarına azimle devam etmelerinin ardında yatan nedenin, bireylerin öz yeterlilik inançlarının yüksek olmasına bağlamışlardır. Yazında, algılanan öz yeterlilik inançları yüksek olan bireylerin, ortaya çıkan bir sorun karşısında çözüm arayışlarında daha sabırlı olduğu ve daha yüksek bilişsel başarı düzeylerine sahip oldukları gözlenmiştir (Bandura, 1986). Aynı şekilde öz yeterliliği yüksek olan insanlar, problemleri etkili bir şekilde çözme yeteneğine sahip olduklarına inanma eğilimindedirler (Chang, Chen, Chuang ve Chou, 2019, s. 104). Buna karşın, bir kişi başarılı olmak için gerekenlere sahip olduğunu düşünmüyorsa, durumla başa çıkma girişiminde bulunma olasıllğı düşük olacaktır (Bandura, 1977). Örneğin; hastanede görev yapan bir hemşirenin sergilemiş olduğu çabalar, yöneticisi ve meslektaşları tarafindan iddialı olmak için gösterilen saldırgan bir tutum olarak görülürse ve çalışana bu algiları yansıtılırsa, çalışan işyerindeki verimliliği konusunda düşük beklentiler içerinde olacaktır. Bu gibi durumlar hemşirelerin, çalışma ortamındaki verimlilik düzeylerini olumsuz yönde etkileyecek ve daha az çaba göstermelerine neden olabilecektir.

Bandura (1977) öz yeterliliğin "büyüklük", "güç" ve "genellenebilirlik" adı verilen 3 boyuta sahip olduğunu dile getirmiştir. Büyüklük Boyutu: Bu boyut kendisine belirli bir zorluk düzeyinde görev verilen kişinin yeterlilik beklentilerinin basit görevler, kısmen zor görevler ve zor görevlerle sınırlandırılmış olacağını ifade etmektedir. Bir görevde aşılması gereken bir engel söz konusu değilse bu görev kolay bir görev olarak adlandırlır ve herkesin aynı şekilde yüksek yeterlilik beklentisine sahip olması beklenir. Ancak başarılı performans çeşitli düzeylerde engellerin ve zorlukların üstesinden gelinmesini gerektiriyorsa alg1lanan yeterliliğin derecesi görevin zorluk düzeyine göre ölçülür. Güç Boyutu: Güçlü beklentilere sahip olan kişiler zorluklarla baş edebilme çabalarını uzun süre koruyabilirken, pekiştirilmemiş zayıf beklentiler kolaylıkla söndürülebilmektedir Genellenebilirlik Boyutu: Öz yeterliliğin bir durumdan diğerine göre değişip değişmediğini veya ne derece değiştiğini göstermektedir (Stajkovic ve Luthans, 1998a, s. 67).

Bandura (1977) bir kişinin öz yeterliliğinin dört temel bilgi kaynağından etkilendiğini söylemiştir. Bu kaynaklar; performans başarıları, güvenilir deneyimler, sözlü ikna ve fizyolojik durumlardır. İstenen bir sonucu elde etme yeteneklerini değerlendirmek için insanlar daha önce neler başardıklarını, kendi fikirlerini ve şu anda nasıl hissettiğini düşünürler. Öz-yeterlilik, insanların ne yapmayı seçtiklerini ve eylemlerinin sonuçlarını nasıl ele aldıklarını etkiler. Bunlar, kendine özgü ortamlarda kendine özgü beklentileri veya öz yeterliliklerinin seviyelerini yansıtmaktadır.

Öz yeterlilik inancı, bireyin motivasyonu, refahı ve kişisel başarısı hususunda temel oluşturmaktadır (Chen, Gully ve Eden, 2004, s. 375). Bu inançlar bireyin görev konusunda davranış sergileme yatkınlı̆ı̆nı, bu davranıştaki devamlilığını, davranış hususunda motivasyonunu ve son olarak da performansını etkilemektedir (Kotaman, 2008, s. 113). Kısacası Öz yeterlik; bir kişinin etkinlik seçimini etkiler, zor olduğu düşünülen görevleri önler ve yönetilebilir olarak kabul edilen faaliyetleri içerir. Sonuç olarak bir kişinin öz yeterliliği ne kadar yüksek olursa, belirli bir görev alanındaki başarı konusunda o kadar kendine güvenecektir. 


\section{Çalışan Performansı}

Çalışan performansı endüstriyel ve örgütsel psikoloji, örgütsel davranış, insan kaynakları yönetimi gibi alanlarda ortaya çıkan çıkan temel bir kavramdır. Son yirmi yıl boyunca, araştırmacılar performans kavramını netleştirme ve genişletme konusunda ilerleme kaydetmişlerdir. Dahası, bireysel performans ile ilgili majör prediktörleri (öngörücüleri) ve süreçleri belirlemede ilerleme kaydedilmiştir (Rehman, Nawaz, Javed, Ahmed ve Malik, 2016, s. 138).

Doğru (2015, s. 58) çalışan performansını, çalışanın gereksinimlerinde tatmin olabilmek için, örgütte üstlendiği görev ve sorumluluklar sonucunda, amaçlarına ulaşabilmek için çaba ve zaman harcaması şeklinde tanımlamıştır. Benligiray (2004, s. 141) çalışan performansını, bir işi yapan bireyin, grubun ya da örgütün, o işle amaçlanan hedefe yönelik olarak neye ulaşabildiğini, neyi sağlayabildiğini nicel ve nitel olarak belirten bir kavram olarak açıklamıştır. Göksel (2013) ise çalışan performansını, bir işletmede çalısan için tanımlanmış, kendi yetenek ve özelliklerine uygun olan bir işi, makul sınırlar içinde gerçekleştirmesi şeklinde ifade etmiştir (Göksel, 2013, s. 4). Çalışan performansı ile ilgili tanımların ortak noktası ise performansın bireysel beklenti ile örgütsel amaç arasında kurulan ilişkinin sonucunda ortaya çıkmasıdır (Tutar ve Altınöz, 2010, s. 202).

Çalışan performansı, örgütler için olduğu kadar çalışanların kendisi için de önemli bir kavramdır. Verilen görevleri başarmış olmanın veya yüksek bir performans düzeyine sahip olmanın hazzı ve gururu, kişi için memnuniyet ve tatmin kaynağıdır (Sonnentag ve Frese, 2002, s. 4). Bununla birlikte, başarı ve yüksek performans güçlü bir öz yeterlilik inancının tesisinde en etkili unsur olarak yer almaktadır.

\section{Öz Yeterlilik ve Performans İlişkisi}

Öz yeterlilik inancı, insanların sergiledikleri davranışları, dolayısıyla performanslarını çeşitli şekillerde etkilemektedir. İlgili yazın ve araştırma bulgularına göre, öz-yeterlilik inancının insan davranışlarına ve performanslarına etkilerini aşağıdaki şekilde açıklamak mümkündür.

- Öz yeterlilik inanc insanlarn tercilerini etkiler: Kişilerin hedefleri, dış referanslar ve öz yeterlilik inançları ile şekillenmektedir ve bu nedenle kişilerin belirleyecekleri hedefler üzerinde öz yeterlilik inançlarının etkisi vardır (Erel, 2000, s. 22). Diğer bir ifade ile kişiler, yeterli olduklarını düşündükleri hedefleri seçecek, yeterli olmadıklarına inandıklarından ise kaçacaklardır. $\mathrm{Bu}$ bağlamda, öz-yeterlilik inancı yüksek olan kişilerin daha büyük hedefler seçerek, daha başarllı olacakları bir gerçektir (Pajares, 2002).

- Öz yeterlilik inanc kişilerin sarf edecekleri çabanm miktarm etkiler: Öz yeterlik inanc1, bir faaliyetle başa çıkarken harcanacak çabanın miktarını, bireyin engeller karşısında ne kadar süre kalacağını ve bireyin olumsuz koşullarda fazlasıyla esnek olabileceğini belirler. Daha yüksek öz yeterliliğe sahip bir birey daha yüksek çaba, kalıcllık ve esneklik gösterebilir. Doğal olarak, yüksek bir öz yeterlilik bireyin çalışma alanında daha iyi performans sergilemesi ile sonuçlanacaktır (Demirtaş, 2018, s. 112). Öz yeterlilik inancı bireysel performansın önemli bir yordayıcısı olarak görülmektedir (Dan vd., 2018, s. 3).

- Öz yeterlilik inancı kişilerin güçlükler karşısındaki direncini etkiler: Belli bir görevi yerine getirebilme konusunda yeterlilik inancı olan kişilerin göreve bağlılıkları daha yüksek olacak ve bu kişiler güçlüklere daha çok direnebilecek, başarısızlık karşısında daha hızlı toparlanabilecektir (Pajares, 2002).

- Özyeterlilik inanc kişilerin düsïnce yapılarm ve duygusal reaksiyonlar etkiler. Olaylarla baş etmede sıkıntı yaşayan, oluşabilecek bir probleme karşı yetersiz olduğunu düşünen, kendine olan güveni zayıf olan, kendisine karşı şüphe besleyen, ilk denemelerinde başarısız olup da tekrar denemelerden kaçan, mutsuz ve umutsuz olan ve sıklıkla savunma mekanizmalarına başvuranlar öz yeterliliği düşük olan kişiler olarak ifade edilmektedir (Yenilmez ve Kakmac1, 2008, s. 5). Zayıf öz-yeterlilik inancına sahip kişiler, işleri olduğundan daha zor görür. Bu durum kişilerde strese neden olurken, başarı konusunda ise daha dar bir görüsşe sahip olmalarına neden olur (Pajares, 2002). Kişiler zorlu yaşam şartlarına karşı farklı tepkiler gösterebilirler. Yüksek öz yeterliğe sahip kişiler karşılaştıkları problemlerin üstesinden gelmek için daha çok çaba gösterirken, düşük öz yeterliğe sahip kişiler daha çabuk vazgeçerek daha az çaba göstermektedirler (Sert ve Traş, 2019, s. 1242).

Öz yeterlilik inancının çalışanlar üzerindeki etkileri sadece bunlarla da sınırlı değildir. İnsan kaynakları yönetimi çerçevesinde gerçekleştirilen araştırmalar, öz yeterlilik inancının yeni çalışanların uyum ve sosyalizasyonu üzerinde etkili olduğunu ortaya koymuştur. Yine, yönetsel yetkinlik ve liderlik unsurlarının 
öz yeterlilik ile ilişkili oldukları tespit edilmiştir. Bunların yanı sıra, öz yeterlilik inançlarının çalışanların sorumluluk almalarıyla da ilişkili olduğu tespit edilmiştir (Erel, 2000, s. 25). Ayrıca, öz yeterlilik inancının çalışanların yenilikçilik ve risk alma özellikleri ile de ilişkili olduğu görülmüştür (Basım, Korkmazyürek ve Tokat, 2008, s. 121). Bu faktörler; aynı zamanda performansla ilişkili özellikler veya yetkinlikler olarak kabul edilebilir.

Öz yeterlilik ve performans ilişkisi çerçevesinde gerçekleştirilmiş araştırmaların en önemlilerinden biri, Stajkovic ve Luthans tarafından 1998 yılında gerçekleştirilen meta-analiz sonuçlarına ilişkin olanıdır. Bu çalışma ile öz yeterlilik inancı ve performans arasında önemli sayılabilecek olumlu ve pozitif bir ilişkinin var olduğu ortaya konulmuştur (Stajkovic ve Luthans, 1998b, s. 256). Konu çerçevesinde gerçekleștirilmiş birçok araştırma ve sonuçları üzerinden oluşturulmuş olan bu çalışma, konu ile ilgili o zamana kadar yapılan araştırmaların bir özeti olduğu için önem taşımaktadır.

Yazında, öz yeterlilik ve çalışan performansı üzerine yapılan araştırmalarda, değişkenler arasında önemli bir ilişkinin olduğu yönündedir ve öz yeterliliğin performans açısından önemli bir kavram olduğunu söylemek yanlış olmayacaktır. Başka bir deyişle, öz yeterlilik inanç düzeyi hem performansı etkilemekte, hem de (gerçekleştirilen) performanstan etkilenmektedir.

\section{Yöntem}

\section{Araştırmanın Amacı ve Önemi}

Öz yeterlilik ve çalışan performansı ile ilgili çalısmaların önemli bir kısmının hizmet sektörü üzerinde akla gelen ilk örneklerden olan sağllk sektörünün tercih edilmesine sebep oluşturmuştur. Bu araştırma ile hemşirelerin öz yeterlilik inanç düzeylerinin performansları üzerindeki etkisinin tespit edilmesi amaçlanmıştır. Daha net bir ifadeyle araştırma, "öz yeterlilik, çalışan performansının öncülü müdür?” şeklindeki temel soruya cevap aramak amacıyla tasarlanmıstır.

Araştırma, sağlık sektörünün araştırmanın değişkenleriyle ilgili olası sorunlarını daha görünür kılmak; öz yeterlilik ve çalışan performansının hemşireler üzerinde ne gibi etkiler bıraktığını belirleme ihtiyacından doğmuştur. Ayrıca, yazında "öz yeterlilik" ve "çalışan performansı" ilişskilerinin varllı̆ını gösteren bulguların yeterli sayıda olmaması bu çalışmanın çıkış noktasını oluşturmaktadır. Öz yeterlilik ve çalışan performansı ilişkisinin yazında daha önce yeterince araştırılmamış olması bu iki değişken arasındaki ilişskinin araştırılması gerektiğini ve bu araştırmanın yazına özgün bir katk1 sunabileceğini düşündürmektedir. Ayrıca çalışmanın öz yeterlilik ve performans kavramlarının farklı perspektiflerde de ele alacak çalışmalara esin kaynağı olabileceği ümit edilmektedir.

\section{Araştırmanın Sınırlılıkları}

Araştırmada sadece Elazı̆̆ il merkezindeki kamu ve özel hastanelerinden veri sağlandığı için elde edilen bulgular ancak Elazı ̆̆ ili için genellenebilir. Araştırmada elde edilen bulguların hemşirelerin tamamına genellenmesi açısından da bazı sınırlılıklar içermektedir. Ayrıca, çalışma çerçevesinde gerçekleştirilen araştırma kapsamında öz yeterlilik inanç düzeyi ile çalş̧an performans arasındaki etkileşimin; "öz yeterlilik inanç düzeylerinin performansa etkisi” itibariyle tek yönlü olarak ele alınması da çalışmanın bir başka sınırlılığıdır.

\section{Araştırmanın Evreni ve Örneklemi}

Elazığ il merkezinde 4’ü kamuya ve 4’ü özel sektöre ait olmak üzere toplam 8 hastane yer almaktadır. Araştırmada kullanılan veriler anket tekniği ile Elazığ il merkezinde bulunan kamuya (Sağlık Bakanlığ1 ve Fırat Üniversitesi) ve özel sektöre ait hastanelerde çalışan hemşirelerden elde edilmiştir.

Elazığ Doğu Anadolu Bölgesi’ndeki diğer illerle karşılaştırıldığında gelişmiş sayılabilecek iller arasındadır. İl devamlı göç almakta ve konum olarak çevredeki illerden gelen hastalara da hizmet vermektedir. Elazığ'da kuruluş yılı 1983 olan yani yaklaşık 36 yıllık bir tecrübeye sahip "Fırat Üniversitesi Hastanesi" yer almaktadır. Neredeyse Cumhuriyet ile yaşıt diyebileceğimiz "Ruh Sağlığı ve Hastalıkları Hastanesi" (Kuruluş-1925) bulunmaktadır. Ayrıca 1945 yılından beri faal olan "Elazığ Eğitim ve Araştırma Hastanesi" eski adıyla "Devlet Hastanesi" de Elazığ iline hizmet sunan bir diğer sağlık işletmesidir. Yaklaşık kırk yıl bağımsız olarak hizmet verdikten sonra "Elazığ Eğitim ve Araştırma Hastanesi" ile birleşen "Deri Hastalıkları Hastanesi" de diğer bir sağlık işletmesi örneği olarak karşımıza çıkmaktadır. İlin diğer bir sağllk işletmesi ise "Diş Hastanesi" dir ve yaklaşık 20 yıldır hizmet vermektedir. Sağllk Bakanlığ1 bünyesindeki hastaneler, Ağustos 2018 itibariyle "Elazığ Şehir Hastanesi" çatısı altında birleştirilmiştir. 
Şehir Hastanesi bölge illeri arasında illk örneği teşkil etmektedir. Kamu hastanelerinin yanı sıra Elazı̆̆ da ayrıca, dört özel hastane (Medicalpark, Anadolu, Hayat, Universal) bulunmaktadır.

$\mathrm{Bu}$ sağlık işletmeleri, Elazığ’’n sağlık sektörü bakımından potansiyeli olan bir il olduğunu göstermektedir. Elazığ, bölgenin sağlık merkezi durumundadır. Elazığ'daki hastaneler gerek ilde gerekse de çevre/bölge illerde bulunan hastalar tarafindan sıklıkla tercih edilmektedir. Bu durum, Elazı̆̆ ilinde görev yapan sağlık çalışanlarının iş yükü yoğunluğunun bir göstergesi olarak kabul edilmekte ve sağlık alanında yapılacak araştırmalar için Elazığ 1 özel hale getirmektedir.

Bu bağlamda, söz konusu hastanelerde çalışan hemşireler araştırmanın evrenini oluşturmaktadır. Elazığ il merkezinde yer alan hastanelerde 1535 hemşire istihdam edilmektedir. Bu sayılar, Aralık 2018 tarihi itibariyle Elazığ İl Sağık Müdürlüğü’nden edinilen bilgiye dayanmaktadır.

Evren büyüklüğünü hesaplama kullanılan formül aşağıda verilmiştir. Evren büyüklüğü 1535 kişidir ve formüle göre örneklem büyüklügü en az 307 (n) olması gerekmektedir. Çalışmamızda örneklem büyüklüğümüzü 309 hemşire oluşturmuştur. Bu sayı ile örneklem büyüklüğünün \% 95 güven düzeyinde evreni temsil gücüne sahip olduğu söylenebilecektir (Hayran, 2012, s. 72).

Örneklem Hacmi

$\mathrm{n}=\mathrm{t} 2 . \mathrm{p} \cdot \mathrm{q} /[\mathrm{d} 2+\mathrm{t} 2 \cdot \mathrm{p} \cdot \mathrm{q} / \mathrm{N}]$

$\mathrm{N}$ : evren büyüklüğ̈̈; t: $\infty$ serbestlik derecesinde teorik t tablo değeri (1,96); p: öngörülen evren oranı $(0,5)$; q: 1-p (0,5); pxq: varyans $(0,25)$; d: oran için öngörülen sapma miktar1-örneklem hatası $(0,05)$.

\section{Değişkenlerin Ölçülmesi}

Öz yeterliliği ölçmek için farklı ölçekler bulunmakla birlikte, bu araştırmada Chen, Gully ve Eden tarafindan 2001 yllında geliştirilen 'Yeni Genel Öz yeterlilik Ölçeği” kullanılmıştır. 8 maddelik ölçeğin öz yeterliliği ölçmeye yönelik olarak hazırlanmış önceki ölçeklerden daha kısa olmasına rağmen, daha geçerli olduğu kanıtlanmıştır (Chen, Gully ve Eden, 2001, s. 79). Çalışan performansı ise Sigler ve Pearson (2000) çalışmalarında kullandıkları ve 4 ifadeden oluşan "Çalışan Performans Ölçeğı" sorularını kapsamaktadır. 4 ifadeden oluşan bu ölçeğin tüm değişkenlerinin güvenilirlikleri (Cronbach’s $\alpha$ katsayıları) kabul edilebilir düzeyin $(0,70)$ üzerinde bulunmuştur.

\section{Araştırmanın Hipotezi ve Modeli}

Yazında, öz-yeterlilik ile yönetimsel fikir üretme (Gist, 1989), hedef belirleme (Locke, Motowidlo ve Bobko, 1986), beceri kazanma (Mitchell, Hopper, Daniels, George-Falvy ve James, 1994), kişisel hedefler (Austin ve Vancouver, 1996; Vancouver, Thompson ve Williams, 2001) ve daha geniş roller üstlenebilme becerisi (Parker, 1998) gibi performans ile bağdaştırilan faktörler arasında ilişkilerin olduğu sonucuna varan çalışmalar mevcuttur. Bu çalşsmaların yanında Judge ve Bono (2001) araştırmalarında meta-analiz sonuçlarına göre, öz yeterliliğin iş performansıyla pozitif ilişkili olduğunu bulmuşladır (Judge ve Bono, 2001, s. 86). Bandura (1986) ise öz yeterliliğin performansla önemli ve pozitif olarak ilişkili olduğunu iddia etmiştir. Öz yeterlilik inancının bireylerin seçimlerini ve performanslarını etkilediğini bulmuştur.

Öz yeterliliğin pozitif etkileri ortaya çıkarılmıştır ve öz yeterliliğin performans üzerindeki etkileri için güçlü deneysel destek mevcuttur. Bu nedenle araştırma literatüründen hareketle aşağıdaki hipotez geliştirilmiştir:

$\mathbf{H}_{1}$ : Hemşirelerin öz yeterlilik inanç düzeylerinin çalışan performansları üzerinde etkisi vardır.

Çalışmanın teorik çerçevesi doğrultusunda geliştirilen öz yeterlilik ve performans ilişkisine yönelik model Şekil 1'de verilmiştir. Şekil-1 öz yeterlilik inanç düzeyinin bağımsız değisşen ve çalısan performansının bağımlı değissken olduğunu göstermektedir. Bu kavramsal model bağımsız değişkenin (öz yeterlilik inanç düzeyi) bağımlı değişken (çalsşan performansı) üzerindeki etkisini analiz etmek için geliştirilmiştir.

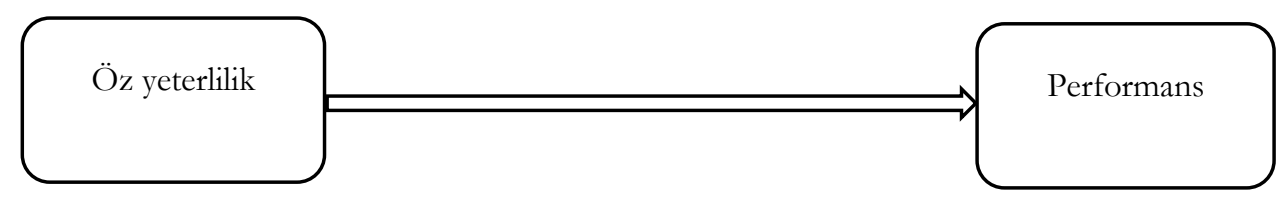

Şekil 1. Kavramsal Araștrma Modeli 


\section{Araştırmanın Veri Toplama ve Analiz Yöntemi}

Araştırma kuramsal çerçeve ve anket uygulaması şeklinde gerçekleştirilmiştir. Bunun yanında araştırmanın konusu hakkında alan yazında yapılan çalışmalar gözden geçirilmiştir. Araştırmada veriler anket uygulanarak elde edilmiş ve elde edilen veriler SPSS 20.0 programı kullanılarak analiz edilmiştir.

Anket üç kısımdan oluşmaktadır. İlk kısımda 8 ifade içeren 'Yeni Genel Öz yeterlilik Ölçeği” yer almaktadır. Yücel (2013) ve Bayram (2014) doktora tez çalışmalarında Öz yeterlilik ölçeğinin Cronbach's Alfa değerleri sırasıyla 0,815-0,824 olarak hesaplanmıştır. İkinci kısımda 4 ifade içeren "İşgören Performans Ölçeği” yer almaktadır. Çöl (2008) araștırmasında Cronbach’s Alfa değeri 0,8277 olarak hesaplanmıştır. Maddeler, 5'li Likert tipi ile derecelendirilmiştir. Seçenekler ise şöyledir: "Kesinlikle Katılmıorum, Katılmıyorum, Kararsızım, Katılıyorum, Kesinlikle Katılıyorum". Ölçeklerde, ters puanlanan madde bulunmamaktadır. Anketin son kısmında ise hemşirelerin demografik özelliklerini (profillerini) belirleyebilmek için toplam 6 soru yer almaktadır.

Veri analizi için kullanılan teknikler ise frekans dağılımı, aritmetik ortalama ve standart sapma yani betimleyici istatistikler, bağlam (zaman, evren, örneklem) farklı olduğu için ölçeklerin geçerlilik (faktör) ve güvenilirlik (cronbach alfa) analizleri ve bağımsız değişken (öz yeterlilik) ile bağımlı değişken (çalışan performansı) arasındaki ilişkinin şeklini, yönünü ve kuvvetini belirleyebilmek için regresyon analizleri şeklinde belirlenmiştir.

\section{Araştırmanın Geçerlilik ve Güvenilirlik Analizi}

Araştırmada ele alınan değişkenlerin normal dağılımı ile ilgili fikir sahibi olunması için basıklık ve çarpıklık değerleri değerlendirilmiştir. Öz yeterlilik ve çalışan performansı değişkenlerine ait basıklık ve çarpıklık değerleri Tablo 1'de verilmiştir.

Tablo 1. Ölçeklere Ait Basıkllk ve Carpıklık Değerleri

\begin{tabular}{lccc}
\hline Ölçekler & $\mathbf{N}$ & Çarpıklık & Basılklık \\
\hline Öz Yeterlilik & 309 & $-1,120$ & 1,692 \\
Çalışan Performansı & 309 &,- 481 &, 250 \\
\hline
\end{tabular}

Tablo 1'de verilen değerler incelendiğinde, Öz yeterlilik ve çalışan performansına ait basıklık ve çarpıklık değerlerinin normal dağılım kriterleri aralığında olduğu, dolayısıyla verinin normal dağıllıma yakın bir dağılım gösterdiği ifade edilebilir. Skewness ve kurtisos (çarpıklık ve basıklık) değerleri -2 ile +2 arasında değer aldığı için değişkenler normal dağılım gösterdiği varsayılmıştır (George ve Mallery, 2010). Bu sebepten dolayı parametrik test teknikleri kullanılmışır.

Sekiz madde ve tek boyuttan oluşan öz yeterlilik ölçeğine, uygulanan açılayıcı faktör analizi sonuçları aşağıdaki tablo 2'de görülmektedir. Açıklayıcı faktör analizi sonuçlarına göre ölçek, özgün çalışmada olduğu gibi tek faktörden oluşmaktadır. KMO değerinin $0,899(p=0,000)$ olması, faktör analizi açısından çok iyi olduğu kabul edilmektedir (Demirel, 2013, s. 230; Karagöz, 2019, s. 953). Cronbach' alfa değerleri sonuçlarına göre; öz yeterlilik inanç düzeyleri ölçeğinin yüksek güvenirlikte olduğu sonucuna ulaşılmıştır (Kılıç, 2016, s. 48). Faktör analizi sonuçları aşağıdaki tabloda aktarılmaktadır:

Tablo 2. Öz Yeterlilik Inanc Açıklayıı Faktör Analiz̨i Sonuçlar

\begin{tabular}{ccccc}
\hline Faktör & Madde No & Faktör Yükleri & Açılklanan Varyans & Cronbach Alpha \\
\hline \multirow{4}{*}{ Öz Yeterlilik } & 3 &, 774 & 46,846 & \\
& 1 &, 751 & \\
& 5 &, 739 & \\
& 7 &, 730 & \\
8 &, 715 & \\
4 &, 711 & \\
6 &, 562 & \\
$\mathrm{KMO}=0,899$ Df $=28$ &, 417 & \\
\hline
\end{tabular}

Dört madde ve tek boyuttan oluşan çalışan performansı ölçeğine, uygulanan açıklayıcı faktör analizi sonuçları aşağıdaki tablo 3'de görülmektedir. Açıklayıcı faktör analizi sonuçlarına göre ölçek, özgün çalışmada olduğu gibi tek faktörden oluşmaktadır. KMO değerinin $0,788(\mathrm{p}=0,000)$ olması, faktör analizi açısından iyi olduğu kabul edilmektedir (Karagöz, 2019, s. 953). Cronbach' alfa değerleri sonuçlarına göre; 
çalışan performansı ölçeğinin orta güvenirlikte olduğu sonucuna ulaşılmıştır (Kılıç, 2016, s. 48). Faktör analizi sonuçları aşağıdaki tabloda aktarılmaktadır:

Tablo 3. Çalışan Performansı Açıklayıı Faketör Analiz̨i Sonucları

\begin{tabular}{ccccc}
\hline Faktör & Madde No & Faktör Yükleri & Açıklanan Varyans & Cronbach Alpha \\
\hline \multirow{2}{*}{ Çalışan Performans1 } & 2 &, 832 & & \\
& 4 &, 798 & 63,267 & \\
& 3 &, 790 & & \\
\hline
\end{tabular}

$\mathrm{KMO}=0,788$ Df=6 App. Chi Square=381,482 $\mathrm{P}=0,000$

\section{Araştırmanın Bulguları}

\section{Katılımc1lara Ait Demografik Bulgular}

Katılımcıların demografik bilgilerinin sunulduğu Tablo 4 aşağıda yer almaktadır. Tablodaki bulgulardan katılımcıların özellikleri şöyle görülmektedir:

Tablo 4. Katullmolarn Demografik Özellikleri ( $n=309)$

\begin{tabular}{|c|c|c|c|c|c|}
\hline Yaş & $\mathbf{F}$ & $\%$ & Medeni Durum & $\mathbf{F}$ & $\%$ \\
\hline 19 yaş ve altı & 41 & 13,3 & Evli & 191 & 61,8 \\
\hline $20-29$ yaş & 112 & 36,2 & Bekâr & 118 & 38,2 \\
\hline $30-39$ yaş & 115 & 37,2 & Meslekte Geçirdiğiniz Toplam Süre & $\mathrm{F}$ & $\%$ \\
\hline 40-49 yaş & 30 & 9,7 & 5 yil ve alt1 & 65 & 21,0 \\
\hline 50 yaş ve üzeri & 11 & 3,6 & $5-10$ yll aras 1 & 66 & 21,4 \\
\hline Cinsiyet & $\mathbf{F}$ & $\%$ & $10-15$ yil arasi & 91 & 29,4 \\
\hline Kadin & 289 & 93,5 & $15-20$ y1l arası & 55 & 17,8 \\
\hline Erkek & 20 & 6,5 & 20 y1l ve üzeri & 32 & 10,4 \\
\hline Ĕ̈itim Düzeyi & $\mathbf{F}$ & $\%$ & $\begin{array}{l}\text { Mevcut Hastanenizde Geçirdiğiniz } \text { Toplam } \\
\text { Süre }\end{array}$ & $\bar{F}$ & $\%$ \\
\hline Lise & 83 & 26,9 & $\begin{array}{l}5 \text { yil ve altı } \\
5-10 \text { vil aras } 1\end{array}$ & $\begin{array}{l}89 \\
83\end{array}$ & $\begin{array}{l}28,8 \\
26,9\end{array}$ \\
\hline Ön lisans & 97 & 31,4 & $10-15$ yil aras & 73 & 23,6 \\
\hline Lisans & 115 & 37,2 & $15-20$ y1l aras 1 & 44 & 14,2 \\
\hline Lisansüstü & 14 & 4,5 & $20 \mathrm{yll}$ ve üzeri & 20 & 6,5 \\
\hline
\end{tabular}

Katılımcıların \% 86,7'si genç ve orta yaş gurubundakilerini, \% 13,3'ü ise orta yaş üzerindekilerini oluşturmaktadır. Katılımcıların \% 61,8'ini evliler, \% 38,2'sini de evli olmayanlar oluşturmaktadır. Katılımcıların \% 93,5’i kadın ve \% 6,5'i erkektir. Katılımcılar arasında eğitim düzeyi açısından ağırlık \% 37,2 ile lisans mezunlarındadır. Lisans mezunlarını \% 31,4 ile ön lisans mezunları, \% 29,9 ile lise mezunlar1 ve \% 4,5 ile lisansüstü eğitim yapmış olanlar takip etmektedir. Katılımcıların \% 42,4’ünün meslekte geçirdikleri toplam süre 10 yıl ve altındayken \% 57,6'sının hastanelerde geçirdikleri toplam süre 10 y1lın üzerindedir. Katılımcıların mevcut hastanelerinde geçirdikleri toplam süre açısından ağırlık \% 55,7 ile 10 yıl ve altında çalışanlar olduğu görülmektedir.

\section{Ölçek Puanları}

Ölçeklerin ortalama puanlarını (her bir önerme için ve genel olarak) değerlendirebilmek adına aritmetik ortalamalar hesaplanmıştır ve bu ölçeklerin ortalamalarının değerlendirilmesinde kabul edilen ölçüt yani puan aralıkları aşağıdaki tabloda verilmiştir. Ölçeğin aralık genişliğinin (dizi genişliği/yapılacak grup sayısı) yani söz konusu puan aralıkları en yüksek puan ile en düşük puanın farkı alınmıştır $(5-1=4)$. Alınan fark ise 5'e bölünmüştür $(4 / 5=0,8)$. Ortaya çıkan değer $(0,8)$, 1'e eklenerek ilk dizi genişliği elde edilmiştir $(1+0,8=1,8)$. Bu aralık (1,00-1,80), ölçekte 1'e (kesinlikle katılmıyorum/hiçbir zaman) karşılık gelen seçeneği temsil etmektedir. Benzer şekilde toplama işlemine devam edilerek her bir seçeneğe karş1lık gelen dizi genişlikleri (puan aralıkları) belirlenmiştir (Emül ve Demirel, 2018, s. 105).

Tablo 5. Ölçek Puanlar

\begin{tabular}{ll}
\hline Puan Aralığ1 & Ölçekteki Karşılı̆̆1 \\
\hline $1,00 \leq \bar{x} \leq 1,80$ & Kesinlikle katılmıyorum \\
$1,80<\bar{x} \leq 2,60$ & Katılmıyorum \\
$2,60<\bar{x} \leq 3,40$ & Kararsızım \\
$3,40<\bar{x} \leq 4,20$ & Katıllyorum \\
$4,20<\bar{x} \leq 5,00$ & Kesinlikle katıllyorum \\
\hline
\end{tabular}


Kullanılan ölçekteki her bir önermenin ya da ölçeğin bütünün ortalaması 3,40 ve altında ise olumsuz/zayıf bir katılımcı tutumunu yansıttığı varsayılmıştır. Aynı şekilde kullanılan ölçekteki her bir önermenin ya da ölçeğin bütünün ortalaması 3,40’’n üzerinde ise olumlu/güçlü bir katıllmc1 tutumunu yansıttı̆̆ı varsayılmıştır.

\section{Öz Yeterlilik Ölçeği Puanları}

Tablo 6'da öz yeterlilik ölçeğinin betimleyici istatistik (ortalama ve standart sapma) değerleri aktarilmaktadir.

Tablo 6. Özyeterlilik İnanc Düzeylerine İliskin Ölçek Puanlar

\begin{tabular}{lccc}
\hline Öz Yeterlilik & Ort. & s.s. & \multicolumn{2}{c}{ Genel } \\
& & & Ort. \\
s.s.
\end{tabular}

Tablo 6'da hemşirelerin öz yeterlilik inanç düzeyleri ortalamasının 4,27 olduğu görülmektedir. Hemşirelerin öz yeterliliklerine ilişkin inançlarının 'kesinlikle katılıyorum" seçeneğine eş olduğu yani olumlu/güçlü olduğu tespit edilmiştir. Her ifadenin ortalamasına ayrı ayrı bakıldığında yüksek algılamalarla karşılaş1lmaktadır. Ancak "kendim için belirlediğim hedeflerin çoğunu gerçekleştirebilirim" ifadesinin diğer ifadelere göre daha yüksek ortalamayı sağladı̆̆ı görülmektedir.

\section{Performans Ölçeği Puanları}

Tablo 7'de performans ölçeğinin betimleyici istatistik (ortalama ve standart sapma) değerleri aktarılmaktadir.

Tablo 7. Calişan Performans Düreylerine İliskin Ölçek Puanlarn

\begin{tabular}{|c|c|c|c|c|}
\hline \multirow[t]{2}{*}{ Performans } & \multirow[t]{2}{*}{ Ort. } & \multirow[t]{2}{*}{ s.s. } & \multicolumn{2}{|c|}{ Genel } \\
\hline & & & Ort. & s.s. \\
\hline 1. Görevlerimi tam zamanında tamamlarım. & 4,33 & 0,70 & & \\
\hline 2. İş hedeflerime fazlasıyla ulaşırım. & 4,13 & 0,80 & & \\
\hline 3. Sunduğum hizmet kalitesinde standartlara fazlasıyla ulaştı̆ımdan eminim. & 4,01 & 0,86 & 4,11 & 0,64 \\
\hline 4. Bir problem gündeme geldiğinde en hızlı şekilde çözüm üretirim. & 3,98 & 0,87 & & \\
\hline
\end{tabular}

Tablo 7'de hemşirelerin performans ortalamasının 4,11 olduğu görülmektedir. Hemşirelerin performanslarına ilişkin algılarının "katılıyorum" seçeneğine eş olduğu yani olumlu/güçlü olduğu tespit edilmiştir. Her ifadenin ortalamasına ayrı ayrı bakıldığında yüksek algılamalarla karşılaşılmaktadır. Ancak "görevlerimi tam zamanında tamamlarım" ifadesinin diğer ifadelere göre daha yüksek ortalamayı sağladığı görülmektedir.

\section{Regresyon Analizi ve Hipotez Testi}

Kurulan regresyon modeli ile araştırmanın temel sorusu olan 'öz yeterlilik, çalışan performansının öncülü müdür?” şeklindeki soruya cevap aranmıştır. Basit doğrusal regresyon analizinden elde edilen sonuçlar aşağıda aktarılmaktadır.

Tablo 8. Regresyon Analizi Sonuçar

\begin{tabular}{lcccccccc}
\hline \multicolumn{1}{c}{ Değişkenler } & \multicolumn{3}{c}{ Performans Ölçeği } & & Korelasyonlar & & \multicolumn{2}{c}{$\begin{array}{c}\text { Coklu Doğrusallik } \\
\text { İstatistikleri }\end{array}$} \\
\hline & Beta & $\mathbf{t}$ & p-değeri & $\begin{array}{c}\text { Zero- } \\
\text { Order }\end{array}$ & Partial & Part & $\begin{array}{c}\text { Tolera } \\
\text { nce }\end{array}$ & VIF \\
\hline Öz yeterlilik Ölçeği & 0,253 & 4,591 & 0,000 & 0,253 & 0,253 & 0,253 & 1,000 & 1,000 \\
$\mathbf{R}$ & 0,253 & & & & & & & \\
$\mathbf{R}^{2}$ & 0,064 & & & & & & & \\
Düzeltilmiş $\mathbf{R}^{2}$ & 0,061 & & & & & & & \\
\hline
\end{tabular}


Değişkenler arasındaki ilişkiyi öğrenebilmek için oluşturulan regresyon modeli 0.05 önem düzeyinde istatistiki açıdan anlamlı ve R2 değerinin 0,064 olarak hesaplandığ1 tablo yardımıyla görülmektedir. R2 değeri (belirlilik ve tanımlayıcılık katsayısı) bağımlı değişkendeki değişimin bağımsız değişkenler tarafından ne kadar tanımlanabildiğini gösteren bir ölçüdür. Buna göre hemşirelerin öz yeterlilik inanç düzeyleri (bağımsız değiş̧ken) çalışan performansını (bağımlı değişkeni) \% 6,4 oranında etkilemektedir. Diğer bir ifade ile bağımsız değişken bağımlı değişkendeki değişimlerin \% 6,4'ünün kaynağıdır. Modelde yer alan değişkenlerden öz yeterlilik inanç düzeyinin $(\beta=0,253: p<0,05)$ performans ölçeği üzerinde bir etkisi olduğu saptanmıştır. Yukarıda ki sonuçlar bağlamında araştırmamızın temel hipotezi olan H1 hipotezi desteklenmiştir.

\section{Tartışma, Sonuç ve Öneriler}

Bugünün rekabet ortamında çalışan performansı, örgütlerin yaşamlarını başarılı bir şekilde devam ettirebilmeleri için üzerinde önemle durulması gereken bir unsurdur. Öz yeterlilik inancı ise, çalışanların performansları üzerine etkili bir unsur olarak ortaya atılmış ve ilgi çekmiş bir kavramdır. Bu bağlamda çalışma ile Elazı̆̆ il merkezinde faaliyet gösteren kamu ve özel hastanelerde çalışan hemşirelerin öz yeterlilik inanç düzeylerinin ne seviyede olduğunu ve bu inançlarının performanslarına ne şekilde etki ettiğini ortaya koymak amaçlanmıştır.

Araştırma sonucunda öz yeterlilik ölçeğine ait ortalama puanı 4,27 olarak belirlenmiştir ve bu puanın olumlu/güçlü olduğu görülmektedir. Aynı ölçeği kullanan Bayram (2014) Denizli ilindeki 3, 4 ve 5 yıldızlı otel işletmelerinde görev alan 48 yönetici ve 181 işgören üzerinde yaptığı çalışmasında, öz yeterlilik ortalama puanını 4,36 olarak saptamıştır. Çalışan Performansı ölçeğine ait ortalama puan ise 4,11 olarak belirlenmiştir ve bu puanın olumlu/güçlü olduğu görülmektedir. Aynı ölçeği kullanan Bayram (2014) performans ortalama puanını 4,32 ve İspir (2018) Kahramanmaraş ilinde bulunan bir kamu kurumunda görev alan 226 kişi üzerinde yaptığı çalısmasında ise performans ortalama puanını 4,13 olarak saptamıştır. $\mathrm{Bu}$ bulgular, araştırma kapsamındaki kurumlarda öz yeterlilik inançlarının ve çalışan performanslarının olumlu/güçlü olduğunu ortaya koymaktadır. Öz yeterlilik ve çalışan performanslarının olumlu/güçlü olması, bir sağlık işletmesi olan hastanelerin rekabet üstünlügü elde edeceğinin ve elde edecekleri bu rekabet üstünlüğünü sürdürebileceğinin, verimli olacağının göstergesi olarak değerlendirilebilir.

Hastane işletmeleri içerisinde çalışan performanslarının arttırılabilmesinin bir yolunun da öz yeterliliği geliştirici uygulamalar olabileceği değerlendirilmektedir. Bu kapsamda araştırma, regresyon analizi sonuçlarının, hemşirelerin öz yeterlilik inançlarının çalışan performansı ile anlamlı ve pozitif bir şekilde ilişkili olduğunu göstermiştir $(\mathrm{r}=0,253, \mathrm{p}<0,01)$. Bu iki değişken arasındaki pozitif ilişki, öz yeterliliğin çalışanların performanslarını belirlemede önemli bir rol oynadığını göstermektedir. Başka bir deyişle, öz yeterlilik arttıkça, çalışan performansı da artar. Aynı zamanda, bu bulgu Carter, Nesbit, Badham, Parker ve Sung (2016) büyük bir metropolde bulunan 20 orta ölçekli şubeden tüm çalışanlar üzerinde; Lee ve Ko (2010); Kore'de altı büyükşehir ve 28 ilde 28 hastanede 182 hemşirelik biriminden seçilen 1996 hemşirelik örneklem üzerinde; Locke, Frederick, Lee ve Bobko (1984) 209 lisans öğrencisi üzerinde; Clercg, Haq ve Azeem (2018) Pakistan kuruluşlarında görev alan yönetici ve çalışanlar üzerinde ve Mathieu ve Button (1992) 135 lisans öğrencisi üzerinde yapılan araştırmaların bulgularıyla da uyumludur. Ayrıca Mitchell vd. (1994), öz yeterliliğin, beklenilen hedeflerden daha iyi bir performans belirleyicisi olduğunu bulmuştur. Benzer şekilde Orpen (1995) Güney Afrika'daki orta ölçekli bir imalat şirketinde görev alan 49 yönetici üzerinde yaptığı çalışmasında, öz yeterlik inancı ve performans arasında anlamlı bir pozitif ilişki elde etmiştir.

Bu çalışma öz yeterlilik ile çalışan performansı arasında işe özgü öz yeterlilik ne kadar yüksek olursa, çalışan performansının da o kadar yüksek olacağını öne süren anlamlı bir ilişki bulmuştur. Böylece, çalışanların performans düzeylerini belirlerken, işe özgü öz yeterliliğin önemli bir rol oynadığ1 sonucuna varılabilir. Bugün araştırmacılar ve uygulayıcılar çalışan performansını artırmak için görev davranışlarına ek olarak ekstra rol davranışlarının da önemini kabul etmişlerdir. Çalışma, çalışanların öz yeterliliklerinin, çalışanların performansını geliştirmek için önemli olduğu sonucuna varmışıı.

Günümüzde sağlık işletmeleri, büyüme, inovasyon, rekabet gücü, hızlı değişim ve riskin kaçınılmaz zorluklarıyla karşı karşıyadır. Bu bağlamda, örgütsel amaç ve hedeflere ulaşmak için, işverenlerin yapıcı eylemlerinin hem kendinde hem de çalışanlarda öz yeterliliği beslemesi gerekmektedir. Öz yeterlilik inançları yüksek olan bir çalışanın, organizasyonda ki motivasyonları ve performansları da yüksek olacaktır. İşverenler, hem bireysel hem de kurumsal performansı iyileştirmek için çalışanların öz yeterliliklerini 
artırmaya odaklanmalıdır. Çalışanların öz yeterliliği; danışmanlık, uygun rehberlik, eğitim ve gelişim programları, zorlu ve özerk işler ve ödüller yoluyla arttır1labilir (Randhawa, 2004, s. 342).

Araştırma, Elazığ il merkezinde faaliyet gösteren kamu ve özel hastanelerde çalışan hemşireler üzerinde yapılmıştır. Elde edilen sonuçların hemşirelerin tümünü baz alarak genelleme yapılması doğru olmayacaktır. Bu nedenledir ki, bulguların benzer araştırmalar ile karşılaştırılması ve değerlendirilmesi açısından farklı illerde yapılması yazına katkı sağlayacaktır. Araştırma iki değişken baz alınarak oluşturulmuştur. Yapılacak olan diğer araştırmalarda, kapsam genişletilerek liderlik stilleri, iş tatmini, örgütsel bağlllık, motivasyon, işten ayrılma niyeti, örgütsel destek, stres vb. farklı değişkenler de analize eklenebilir. Hatta bu bağlantılar için farklı değişkenler ile aracı rol veya düzenleyici rollerin keşfedilmesi araştırmacılara bir avantaj yaratacağı düşünülmektedir.

\section{Etik Beyan}

"Hemsirelerin Öz Yeterlilik İnanc Düzeylerinin Performanslar Üzerindeki Etkisi: Elaž̆ğ İli Örneğ̈" başlıklı çalısmanın yazım sürecinde bilimsel, etik ve alınt kurallarına uyulmuş; toplanan veriler üzerinde herhangi bir tahrifat yapılmamış ve bu çalışma herhangi başka bir akademik yayın ortamına değerlendirme için gönderilmemiştir.

\section{Kaynakça}

Austin, J. T. ve Vancouver, J. B. (1996). Goal Constructs in Psychology: Structure, Process, and Content. Psychological Bulletin, 120(3), 338-375.

Bandura, A. (1994). Self-Efficacy. In V. S. Ramachaudran (Ed.), Encyclopedia Of Human Behavior (pp. 71-81). New York: Academic Press.

Bandura, A. (1977). Social Learning Theory. Englewood Cliffs, NJ: Prentice-Hall.

Bandura, A. (1986), Social Foundations of Thought and Action: A Social Cognitive Theory. Englewood Cliffs, NJ: PrenticeHall.

Basım, N.J., Korkmazyürek, H. ve Tokat, A.O. (2008). Çalışanların Öz Yeterlilik Algılamasının Yenilikçilik ve Risk Alma Üzerine Etkisi: Kamu Sektöründe Bir Araştırma, Selçuk Üniversitesi SBE Dergisi, 19, 121-130.

Bayram, Ü. (2014). Turizm Sektörü ve Yöneticileri Arasnda Pygmalion Etkisi: Otel Issletmelerinde Bir Uygulama (Doktora Tezi). Gazi Üniversitesi Eğitim Bilimleri Enstitüsü, Ankara.

Benligiray, S. (2004). Insan Kaynaklar Yönetimi. Eskişehir: Anadolu Üniversitesi.

Carter, W.L., Nesbit, P.L., Badham, R.J., Parker, S.K. ve Sung, L.-K. (2016). The Effects of Employee Engagement and Self-Efficacy on Job Performance: A Longitudinal Field Study. The International Journal of Human Resource Management, 29(17), 2483-2502. doi: 10.1080/09585192.2016.1244096.

Cattelino, E., Morelli, M., Baiocco, R. ve Chirumbolo, A. (2019). From External Regulation to School Achievement: The Mediation of Self-efficacy at School. Journal of Applied Developmental Psychology, 60, 127-133.

Chang, Y-S., Chen, M.Y-C., Chuang, M-J. ve Chou, C-H. (2019). Improving Creative Self-Efficacy and Performance Through Computer-Aided Design Application. Thinking Skills and Creativity, 31, 103-111.

Chen, G., Gully, S. M. ve Eden, D. (2001). Validation of a New General Self-Efficacy Scale. Organizational Research Methods, 4(1), 62-83.

Chen, G., Gully, S. ve Eden, D. (2004). General Self-Efficacy and Self-Esteem, Toward Theoretical and Empirical Distinction between Correlated Self-Evaluations. Journal of Organizational Behavior, 25(3), 375-395.

Clercq, D.D., Haq, I.U. ve Azeem, M.U. (2018). Self-Efficacy to Spur Job Performance: Roles of Job-Related Anxiety and Perceived Workplace Incivility. Management Decision, 56, 891-907.

Çöl, G. (2008). Algglanan Güçlendirmenin İșgören Performansı Üzerine Etkileri. Doğuș Üniversitesi Dergisi, 9(1), 35-46.

Dan, X., Xu, S., Liu, J., Hou, R., Liu, Y. ve Ma, H. (2018). Relationships Among Structural Empowerment, Innovative Behaviour, Self-Efficacy, and Career Success in Nursing Field in Mainland China. International Journal of Nursing Practice, 24, 1-9.

Demirel, E.T. (2013). Mesleki Stresin İş Tatminine Etkisi: Örgütsel Desteğin Aracıllk Rolü. Niğde Üniversitesi İIBF Dergisi, 6(1), 220-241.

Demirtaş, V.Y. (2018). A Study on Teacher Candidates' Self-Efficacy, Motivation and Affection Levels for Children. Journal of Education and Training Studies, 6(12), 111-125.

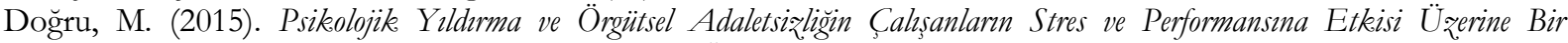
Araştrrma (Yüksek Lisans Tezi). Gebze Teknik Üniversitesi Sosyal Bilimler Enstitüsü, Gebze.

Emül, E. ve Demirel, E.T. (2018). Etik İklim Algısının Hasta Güvenliği Kültürü Üzerine Etkisi: Elazığ Örneği. Turkish Studies, 13(7), 83-122.

Erel, D. (2000). The Concept of Self-Efficacy and Self-Efficacy-Performance Relationship. Ankara Üniversitesi SBF Dergisi, 55(4), 13-35.

George, D. ve Mallery, M. (2010). SPSS for Windows Step by Step: A Simple Guide and Reference, 17.0 update (10a ed.) Boston: Pearson. 
Gist, M. E. (1989). The Influence of Training Method on Selfefficacy and Idea Generation Among Managers. Personnel psychology, 42(4), 787-805.

Goodwin, E.V. (2016). The Effects of Male Leadership on Workplace Gender Identity, Self-Efficacy, and Career Aspirations of Women Working in College Atbletics (Doctoral Dissertation). Miami University, Ohio.

Göksel, A. (2013). İsletmelerde Performans Değerleme Sistem Tasarım (2. Baskı). Ankara: Nobel Akademik Yayıncılık.

Hayran, O. (2012). Sağlk Bilimlerinde Arastırma ve Istatistik Yöntemler, İstanbul: Nobel Tip Kitabevleri.

Heslin, P.A. ve Khele, U.C. (2006). Self-Efficacy. In S. G. Rogelberg (Ed.), Encyclopedia of Industrial / Organizational Psychology (pp. 705-708).

İspir, İ. (2018). Çalışanların İş Tatmini İle Yenilikçi Davranışının Bireysel Performansa Etkisi, İnönü Üniversitesi Uluslararası Sosyal Bilimler Dergisi, 7(2), 120-135.

Judge, T.A. ve Bono, J.A. (2001). Relationship of Core Self-Evaluations Traits-Self-Esteem, Generalized SelfEfficacy, Locus of Control, and Emotional Stability-With Job Satisfaction and Job Performance: A MetaAnalysis. Journal of Applied Psychology, 86, 80-92.

Karagöz, Y. (2019). SPSS-AMOS-META Uygulamal İstatistiksel Analižler (2. Baskı). Ankara: Nobel Yayın Dağıtım.

Kilıç, S. (2016). Cronbachs Alpha Reliability Coefficient. Journal of Mood Disorders, 6(1), 47-48.

Kotaman, H. (2008). Öz Yeterlilik İnanc1 ve Öğrenme Performansının Geliştirilmesine İlişkin Yazın Taraması. Uludağ Üniversitesi Eğitim Fakültesi Dergisi, 21(1), 111-133.

Latikka, R., Turja, T. ve Oksanen, A. (2019). Self-efficacy and Acceptance of Robots. Computers in Human Behavior. 93, 157-163.

Lee, T.W. ve Ko, Y.K. (2010). Effects of Self-Efficacy, Affectivity and Collective Efficacy on Nursing Performance of Hospital Nurses. Journal of Advanced Nursing, 66(4), 839-848.

Locke, E.A., Frederick, E., Lee, C. ve Bobko, P. (1984). Effect of Self-Efficacy, Goals, and Task Strategies on Task Performance. Journal of Applied Psychology, 69(2), 241-251.

Locke, E.A., Motowidlo, S.J. ve Bobko, P. (1986). Using Self-efficacy Theory to Resolve the Conflict between GoalSetting Theory and Expectancy Theory in Organizational Behavior and Industrial/Organizational Psychology. Journal of Social and Clinical Psychology, 4(3), 328-338.

Mathieu, J.E. ve Button, S.B. (1992). An Examination of the Relative Impact of Normative Information and Self Efficacy on Personal Goals and Performance Over Time. Journal of Applied Social Psychology, 22(2), 17581775.

McCauley, D.M., Weymouth, B.B., Feinberg, M.E. ve Fosco, G.M. (2019). Evaluating School and Peer Protective Factors In The Effects of Interparental Conflict on Adolescent Threat Appraisals and Self-efficacy. Journal of Adolescence, 71, 28-37.

Mitchell, T. R., Hopper, H., Daniels, D., George-Falvy, J. ve James, L. R. (1994). Predicting Self-efficacy and Performance during Skill Acquisition. Journal of Applied Psychology, 79(4), 506-517.

Muslichah (2018). The Effect of Self Efficacy and Information Quality on Behavioral Intention with Perceived Usefulness as Intervening Variable. Journal of Accounting-Business \& Management, 25(1), 21-34.

Orpen, C. (1995). Self-efficacy Beliefs and Job Performance Among Black Managers in South Africa. Psychological Reports, 76(2), 649-650.

Pajares, F. (2002). Overview of Social Cognitive Theory and of Selfefficacy. https://www.uky.edu/ eushe2/Pajares/eff.html (Erişim Tarihi:02/01/2019).

Parker, S.K. (1998). Enhancing Role Breadth Self-Efficacy: The Roles of Job Enrichment and Other Organizational Interventions. Journal of Applied Psychology, 83(6), 835-852.

Randhawa, G. (2004). Self-Efficacy and Work Performance: An Empirical Study. Indian Journal of Industrial Relations, 39(3), 336-346.

Rehman, F-ur, Nawaz, T., Javed, F., Ahmed, I. ve Malik, M.I. (2016). Determining the Influence of Organizational Culture on Employee Performance: The Moderating Role of Self-Efficacy. European Journal of Business and Management, 8(4), 136-143.

Sert, M. ve Traş, Z. (2019). Ergenlerin Duygusal Zekâ Düzeyleri İle Öz-Yeterlik Algıları Arasındaki İlişkinin İncelenmesi. Manas Sosyal Arastırmalar Dergisi, 8(1), 1239-1254.

Sonnentag, S. ve Frese, M. (2002). Performance Concepts and Performance Theory. In S. Sonnentag (Ed.), Psychological Management of Individual Performance (pp. 4-25). John Wiley \& Sons, Ltd.

Spector, P.E. (2008). Industrial and Organizational Psychology: Research and Practice (5 $5^{\text {th }}$ Edition). New Jersey: John Wiley \& Sons, Ltd.

Stajkovic, A.D. ve Luthans, F. (1998a). Social Cognitive Theory and Self-Efficacy: Going Beyond Traditional Motivational and Behavioral Approaches. Organizational Dynamics, 26(4), 62-74.

Stajkovic, A.D. ve Luthans, F. (1998b). Self Efficacy and Work Related Performance: A meta-analysis. Psychological Bulletin, 124(2), 240-261.

Top, M., Gider, Ö. ve Ünalan, D. (2010). Hastane Sektöründe İş Performansını Etkileyen Örgütsel Değişkenlerin (Faktörlerin) İncelenmesi: Kayseri ve Kocaeli İllerindeki Hemşireler Üzerine Bir Alan Araştırması. İstanbul Üniversitesi Issletme Fakültesi Issletme İktisadı Enstitüsü Yönetim Dergisi, 21(66), 71-96.

Tutar, H. ve Altınöz, M. (2010). Örgütsel İklimin İşgören Performansı Üzerine Etkisi: Ostim İmalat İşletmeleri Çalışanları Üzerine Bir Araştırma. Ankara Üniversitesi SBF Dergisi, 65(2), 195-218.

Vancouver, J. B., Thompson, C. M. ve Williams, A. A. (2001). The Changing Signs in the Relationships among Selfefficacy, Personal Goals, and Performance. Journal of Applied Psychology, 86(4), 605-620. 
Yenilmez, K. ve Kakmac1, Ö. (2008). İlköğretim Matematik Öğretmenliği Bölümü Öğrencilerinin Öz Yeterlilik İnanç Düzeyleri. Eskişehir Osmangazi Üniversitesi Sosyal Bilimler Dergisi, 9(2), 1-21.

Yücel, D. (2013). Pygmalion Etkisi Kapsamında Yönetici Beklentilerinin Astlar Tarafindan Algzlanmasının Astlarm Performans Üzerindeki Etkileri ve Bir Araștırma (Doktora Tezi), Marmara Üniversitesi Sosyal Bilimler Enstitüsü, İstanbul.

\section{EXTENDED ABSTRACT}

The increasing competition with globalization has made the efficiency and productivity of human resources, which have a vital importance in the success of today's hospitals, even more important. Every element that affects employee performance, which is the main source of efficiency and productivity, attracts the attention of managers and researchers. The increasingly challenging conditions of business life, the fundamental element of the success of organizations, require more emphasis on issues and concepts that may have an impact on employee performance, and these concepts are becoming increasingly important in the eyes of managers and researchers. In this way, one of the concepts that can be said to have an impact on employee performance is the concept of self-efficacy belief, which is expressed as the beliefs of the employees in the capacity they need to perform a particular job or task. Self-efficacy belief is a concept that expresses the belief that one can do a particular job, and whether this belief is low or high affects performance.

Subject of the Research: In the study, firstly a general framework on self-efficacy and employee performance is tried to be created in theoretical terms. Then it was examined the relationship between self-efficacy and performance. In the research section, which is the last part of the study, the results of the face-to-face surveys with the nurses working in the hospitals operating in the city center of Elazığ were transferred and the results were evaluated.

Purpose of the Research: In this research, it is aimed to reveal how nurses' self-efficacy belief levels are reflected in their performance. With a clearer expression, the research is designed to answer the basic question of "self-efficacy, is the premise of employee performance?"

Importance of the Research: In the literature, it was determined that the studies on self-efficacy and performance interaction were not sufficient in numerical terms. It is thought that there is an important gap in terms of field writing. Therefore, it is hoped that the self-efficacy and performance concepts of the study will be a source of inspiration for the studies that will be discussed in different perspectives.

Method of the Research: Although there are different scales to measure self-efficacy in the literature, New General Self Efficacy Scale developed by Chen et al. in 2001 was used in this research. Although the 8-item scale was shorter than the previous scales prepared for measuring self-efficacy, it proved to be more valid (Chen et al., 2001). Employee performance includes performance scale questions that is Sigler and Pearson (2000) used in their work and consisted of 4 statements. As the reliability of the questionnaire questions was considered positive in previous studies, it was considered as a data for this research. The survey consists of three parts. In the first part, demographic characteristics are used to determine the profile of nurses. The second part consists of surveys on nurses' self-efficacy belief levels. The third and last part is composed of employee performance survey questions. The degree of participation of the answers which obtained from the questions in the second and third part is increasing relatively from 1 to 5. For this reason, the total weighted ratios of the options were determined by weighting the options listed according to the degree of participation. SPSS package program was applied to evaluate such questions and results.

\section{Findings}

- $86.7 \%$ of the participants were young and middle-aged, and $13.3 \%$ of are those over the middle age.

- $61.8 \%$ of the participants were married and $38.2 \%$ were unmarried.

- $93.5 \%$ of the participants were female and $6.5 \%$ were male.

- Majority of the sample $37.2 \%$ of the participants in terms of education level belong to undergraduate graduates.

- The total time spent by $42.4 \%$ of the participants in the profession is 10 years or less. The total time spent in hospitals by $57.6 \%$ of the participants is over 10 years.

- It is seen that $55.7 \%$ of the participants were working in their existing hospitals and 10 years or less. 
The study findings showed that the nurses' self-efficacy belief levels $(\bar{X}=4.27$; sd $=0.52)$ and performances $(\bar{X}=4.11$; sd $=0.64)$ was high. Self-efficacy belief levels was found to have a positive medium-level effect on employee performance. Self-efficacy may be effective at a rate of $6 \%$ on employee performance $(\mathrm{r}=0.253 ; \mathrm{r} 2=0.064 ; \mathrm{p}<0.001)$.

Conclusion: This study found a significant relationship between self-efficacy and employee performance, suggesting that the higher the specific self-efficacy, the higher the employee performance. Thus, while determining the performance levels of employees, it can be concluded that work-specific selfefficacy plays an important role. Today, researchers and practitioners have acknowledged the importance of extra role behaviors in addition to their task behavior to improve employee performance. The study concluded that the self-efficacy of the employees is very important to improve the performance of the employees.

Today organizations face the inevitable challenges of growth, innovation, competitiveness, rapid change and risk. In this context, in order to attain the organizational goal of productivity, constructive actions on the part of employers are required to nurture self-efficacy, both in themselves and in employees. Efficacy beliefs influence how employees feel and motivate themselves and thus these beliefs contribute significantly to employee's motivation and performance in organization. Employers should focus on improving employee's self-efficacy in order to improve both individual and organizational performance. Employee's self-efficacy can be enhanced through counseling, proper guidance, training and development programmes, challenging and autonomous jobs and rewards (Randhawa, 2004).

This study provides many potential ways for future researchers. In this study self-efficacy and employee performance constitute the main variables. In addition to this, it may be fruitful to investigate how self-efficacy regulates other areas in an organization (leadership styles, job satisfaction, organizational commitment, motivation, intention to leave, organizational support, stress, etc.). That is to say, Our research was presented by taking only two variables. In other studies, different variables can be added to the analysis by keeping the scope wide. In fact, it is thought that it will be an advantage for researchers to discover the mediating role or regulatory roles for these connections. 